\title{
COMMUTING TIME AND LIFE SATISFACTION OF HIGH SCHOOL STUDENTS IN THE CZECH REPUBLIC, ITALY AND SLOVENIA*
}

\section{Julius Janáček ${ }^{a}$, Václav Rybáček ${ }^{a}$}

\begin{abstract}
This study is a contribution to research into the relationship between commuting and life satisfaction. Our focus is on high school students. The research is based on a questionnaire survey among students in three countries: the Czech Republic, Italy and Slovenia. The analysis is conducted using six OLS regression models: three countries and both boys and girls in each country. The results show significant variance between the countries as far as the relation between commuting time and life satisfaction is concerned. A strong relation has been found only in the case of the Czech Republic. Possible reasons for this disparity include differences in the way various modes of transportation affect one's commuting experience, the role of climate and cultural aspects. In addition, variance has been found between the way boys and girls approach as well as experience commuting. Finally, our results confirm that commuting is a highly underestimated factor of happiness among students.
\end{abstract}

Keywords: Life satisfaction, students, commuting, survey

JEL Classification: D10, I31, R23

\section{Introduction}

The relation between commuting and life satisfaction has gained wide attention from researchers over the last several decades. Generally, daily commuting time turns out to be a significant factor negatively influencing people's life satisfaction ${ }^{1}$ (Diener et al., 2009).

a Jan Evangelista Purkyne University in Usti nad Labem, Faculty of Social and Economic Studies, Ústí nad Labem, Czech Republic

Email: julius.janacek@ujep.cz,vaclav.rybacek@ujep.cz

* This article was created with the support of the Smart project (grant number: CZ.02.1.01/0.0/0.0/1 7_048/0007435), University of Jan Evangelista Purkyne, Ústí nad Labem, Czech Republic.

1 Although the terms happiness and life satisfaction may have a different meaning for many people and they are strictly separated in many scientific disciplines, in this paper we follow the practice of economics of happiness and use these terms interchangeably. A more detailed explanation is offered, e.g., by Frey (2008). 
Similarly, Frey and Stutzer (2010) found that life satisfaction decreases along with the growing distance a person has to commute. In this study, we focus on the relation between commuting and life satisfaction of high school students.

Commuting is directly connected with many areas of life, which applies to students as well. For example, Astin (1984) and Chickering (1974) found that student commuters expressed a lower satisfaction with their college experience than those who were residents of the student dormitories. These two studies demonstrate the first negative aspect of commuting: long trips take away people's time that could be used for various beneficial activities and thus decreases people's potential to improve their well-being. The second aspect of commuting has to do with the activity itself - travelling can be unpleasant and tiring. Thus, it can directly lower people's happiness (Frey, 2008).

Admittedly, another important aspect directly related to commuting is the choice of the mode of transport. St-Louis et al. (2014) investigated people's preferences of transportation modes and how various means of transportation affect people's satisfaction with the trip. Likewise, Fordham et al. (2017) scrutinized the relation between the means of transportation and the effect on life satisfaction among students, staff and faculty at McGill University in Montreal, Canada. Both of these studies found that different ways of travelling exhibit different satisfaction patterns. For example, active commuting (walking or cycling) usually has a positive effect on happiness. This corresponds to findings of many other studies (Ying et al., 2015; Legrain et al., 2015; Whalen et al., 2013).

On the other hand, Biddix (2015) found no significant change in well-being between commuter and non-commuter students. No strong relationship between the duration of the commute and life satisfaction was found in the study of Chatterjee et al. (2017). The aforementioned findings do not provide uniform conclusions. However, these contradicting studies were conducted in different environments and social backgrounds. If we take into account all conditions related to people's lives, we could possibly explain these differences. The worthiness of this study is supported by the fact that the level of life satisfaction has an impact on students' academic performance (Rode et al., 2005). The aim of this article is to bring a modest contribution to this discussion based on an investigation in three countries simultaneously. This is a rather unique approach, which could help to explain the aforementioned seemingly contradictory results.

Another aspect addressed in the paper is whether students downgrade commuting as a significant factor of life satisfaction. Frey (2008) showed that this is usually the case in the adult population. Underestimation or overestimation of certain well-being factors results in biased decision-making in everyday life; decision-makers then end up "less satisfied with life than they could be according to their own evaluation" (Frey, 2008, p. x). 
Knowing this, an individual has a strong incentive to take an introspective look and to re-evaluate their priorities. Thus, our work has the potential to increase students' quality of life by simply informing them about the factors found in our research. Besides this, it can offer a basis for further economic policy recommendations aiming at the promotion of people's quality of life.

\section{Methodology}

Our research is based on the analysis of questionnaire results collected from students in three countries: the Czech Republic, Italy and Slovenia. The data comes from 11 Czech schools, 6 Italian schools and 12 Slovenian schools. Our sample consists of 3,841 high school students: 1,564 Czechs, 800 Italians and 1,477 Slovenians.

Uchida et al. (2004) showed that factors related with life satisfaction can be different in countries that have different cultural backgrounds. We intentionally selected three countries that are located in a similar region, yet have different ways of living, values and traditions. In this way, we can verify whether the findings of Uchida et al. (2004) apply to the European student population as well when studying the role of commuting. The selection of countries was also subject to legislative limitations for conducting surveys - for example, questionnaire distribution is strictly regulated in Turkey or Germany.

The Czech schools are in cities and towns that lie in the northwestern part of the Czech Republic (Ústí nad Labem, Teplice, Most, etc.), the Italian schools are in the regions of Teramo, Genova and Rome, while the Slovenian schools are in Celje, Maribor and Ljubljana. Our aim was to collect data from around 1500 students in each country. Unfortunately, the Italian postal service proved to be an unreliable collaborator by failing to deliver questionnaires from half of the schools. This is the reason for the lower number of students from Italy in our sample.

The survey was conducted at schools which are in some way affiliated to our university or to our co-workers. Therefore, the school selection was not random. This is also the reason why the Czech students come from larger towns than the Italians and Slovenians (see population means in Table 2). This is a potential limitation of our analysis. However, in each country we selected schools of the same type - all of them offer general education and all of them educate both boys and girls. Therefore, the data from all three countries are comparable. The uniqueness of our dataset lies in the fact that there has not yet been any study in this area of research that would encompass so many high school students from three different countries.

The survey was conducted in November 2017. In each school, the questionnaires were distributed and completed by all students in the school during a single day. 
The questionnaire consists of many questions related to different areas of students' life. From the general questionnaire, we selected 19 questions in advance to incorporate into our study. Table 1 presents all of these variables along with the applicative questions and scales.

Table 1: Variables and their description

\begin{tabular}{|c|c|c|}
\hline Variable & Question & Scale \\
\hline Life Satisfaction & $\begin{array}{l}\text { How would you evaluate the quality of your current life } \\
\text { on a scale from } 0 \text { to } 10, \text { where } 0 \text { is the lowest quality } \\
\text { and } 10 \text { is the highest quality? }\end{array}$ & $0-10$ \\
\hline Population & What is the population size of your village/town/city? & Integer \\
\hline Commuting Time & How long do you commute to school every day? (min) & Integer \\
\hline Cigarettes & How many cigarettes do you smoke on average per day? & Integer \\
\hline $\begin{array}{l}\text { Allowance } \\
\text { (per month) }\end{array}$ & $\begin{array}{l}\text { What is your monthly allowance from your parents? } \\
\text { (local currency) }\end{array}$ & $\begin{array}{l}\text { Integer (subsequently } \\
\text { recalculated to euros) }\end{array}$ \\
\hline $\begin{array}{l}\text { Gifts Spent } \\
\text { (per year) }\end{array}$ & $\begin{array}{l}\text { How much money do you spend on average on gifts per } \\
\text { year? (local currency) - proxy variable for generosity }\end{array}$ & $\begin{array}{l}\text { Integer (subsequently } \\
\text { recalculated to euros) }\end{array}$ \\
\hline Sport Time & $\begin{array}{l}\text { How many hours on average do you spend doing some } \\
\text { sport activities per week? }\end{array}$ & Integer \\
\hline TV Time & $\begin{array}{l}\text { How many hours on average do you spend watching TV } \\
\text { per week? }\end{array}$ & Integer \\
\hline Time with Friends & $\begin{array}{l}\text { How many hours on average do you spend with your } \\
\text { friends per week? }\end{array}$ & Integer \\
\hline $\begin{array}{l}\text { Regular } \\
\text { Breakfast }\end{array}$ & $\begin{array}{l}\text { To what extent is this statement true for you: } \\
\text { "I have breakfast regularly"? - proxy variable for leading } \\
\text { a structured life }\end{array}$ & $0-10$ \\
\hline $\begin{array}{l}\text { Relationship } \\
\text { with Parents }\end{array}$ & $\begin{array}{l}\text { My relationship with my parents (both-sided aspect) is... } \\
\text { (-5 completely negative, } \ldots, 5 \text { completely positive). }\end{array}$ & -5 to 5 \\
\hline $\begin{array}{l}\text { Financial Situa- } \\
\text { tion Evaluation }\end{array}$ & $\begin{array}{l}\text { I asses my financial situation as ... ( }-5 \text { completely } \\
\text { negative, } \ldots, 5 \text { completely positive). }\end{array}$ & -5 to 5 \\
\hline Health Physical & $\begin{array}{l}\text { To what extent is this statement true for you: } \\
\text { "I am physically healthy"? }\end{array}$ & $0-10$ \\
\hline Business Future & $\begin{array}{l}\text { To what extent is this statement true for you: } \\
\text { "I will work in business"? }\end{array}$ & $0-10$ \\
\hline Partner & Do you have a partner? & No/Yes - 0/1 \\
\hline Live with Parents & Do you live with your parents? & No/Yes - 0/1 \\
\hline Gender & What is your gender? & Male/Female - 0/1 \\
\hline Age & Please state your age... & $15-20$ \\
\hline
\end{tabular}

Source: Authors' own work. 
Although the focus of this study is the relation between commuting and life satisfaction, the other questions were included in our analysis in order to control for different aspects also related to life satisfaction. In a pilot survey in one school, we also inquired about the type of transportation the students use when they commute. Since most students did not complete this information, we did not include this question in our main survey. However, we asked the schools about the type of transportation their students usually use. The Czech schools replied that their students usually use trains. The Italian and Slovenian schools replied that their students usually use buses and occasionally they use their private cars. Although this is not statistically precise information, we can incorporate it into our analysis when studying the role of commuting in these three countries. The values of the financial variables (allowance and gifts spent) were converted into euros (the Czech Republic uses Czech crowns). Also, in order to get comparable price levels, the financial values were recalculated according to purchasing power parity using 2017 data provided in the Organization for Economic Cooperation and Development (OECD) database ${ }^{2}$.

The question "How would you evaluate the quality of your current life on a scale from 0 to 10 , where 0 is the lowest quality and 10 is the highest quality?" to inquire about students' life satisfaction is also used in the annual World Happiness Report conducted by the United Nations (Helliwell et al., 2018; Helliwell et al., 2019). Besides, this question is used in many economics of happiness studies. More detailed discussion of different methods and possible pitfalls of measuring happiness is offered in Frey (2008, pp. 139-143). For the purpose of this research, it is sufficient to know that different methods and scales used to measure life satisfaction correlate with each other (Fordyce, 1988). This means that we will be able to compare our results with other happiness studies.

We investigate the relation between commuting time and happiness in six groups: in each country, we investigated the boys' and girls' relationship separately. Table 2 shows the mean values and standard deviations using this division.

As far as the variables of life satisfaction and commuting time are concerned, the Czech Republic and Slovenia show similar patterns - both their mean values and standard deviations are very much alike. The Italians seem to be different - they commute less, yet they are also significantly less happy. In addition, their standard deviations for happiness are considerably higher. This could be attributed to different understandings when it comes to the question inquiring about life satisfaction in different social groups, as suggested by Kahneman-Riis (2005). On the other hand, Helliwell (2006) argues that this is not the case and that such differences simply imply different happiness levels. One could think that the Italians might be less happy in general and that this applies to students in our schools as well. 
Table 2: Mean values

\begin{tabular}{|c|c|c|c|c|c|c|c|c|}
\hline \multirow{2}{*}{ Variable } & & \multirow{2}{*}{$\begin{array}{c}\text { All } \\
\text { students }\end{array}$} & \multicolumn{2}{|c|}{ Czech Republic } & \multicolumn{2}{|c|}{ Italy } & \multicolumn{2}{|c|}{ Slovenia } \\
\hline & & & Boys & Girls & Boys & Girls & Boys & Girls \\
\hline \multirow{2}{*}{$\begin{array}{l}\text { Life } \\
\text { Satisfaction }\end{array}$} & Mean & 7.25 & 7.38 & 7.18 & 6.44 & 6.24 & 7.72 & 7.69 \\
\hline & St. Dev. & 1.96 & 1.88 & 1.79 & 2.14 & 2.38 & 1.75 & 1.69 \\
\hline \multirow{2}{*}{$\begin{array}{l}\text { Commuting } \\
\text { Time }\end{array}$} & Mean & 29.16 & 30.51 & 29.05 & 24.76 & 21.86 & 32.49 & 30.79 \\
\hline & St. Dev. & 20.96 & 24.00 & 21.66 & 14.99 & 13.29 & 21.65 & 21.04 \\
\hline \multirow{2}{*}{ Population } & Mean & 44,444 & 98,198 & 50,357 & 30,896 & 34,953 & 19,325 & 20,776 \\
\hline & St. Dev. & 148,729 & 268,518 & 164,420 & 43,363 & 57,275 & 47,816 & 49,170 \\
\hline \multirow{2}{*}{ Cigarettes } & Mean & 2.36 & 2.23 & 2.41 & 2.08 & 1.73 & 2.68 & 2.61 \\
\hline & St. Dev. & 4.95 & 5.06 & 4.87 & 5.09 & 4.91 & 5.08 & 4.66 \\
\hline \multirow{2}{*}{ Allowance } & Mean & 92.46 & 40.75 & 36.51 & 214.96 & 218.06 & 82.78 & 81.95 \\
\hline & St. Dev. & 4.95 & 5.06 & 4.87 & 5.09 & 4.91 & 5.08 & 4.66 \\
\hline \multirow{2}{*}{ Gifts Spent } & Mean & 215.99 & 150.87 & 151.31 & 498.46 & 530.07 & 103.29 & 146.70 \\
\hline & St. Dev. & 524.25 & 193.02 & 156.52 & 323.75 & 347.49 & 184.48 & $1,077.36$ \\
\hline \multirow{2}{*}{ Sport Time } & Mean & 6.47 & 7.28 & 5.28 & 7.49 & 7.51 & 7.15 & 4.99 \\
\hline & St. Dev. & 5.57 & 6.83 & 5.86 & 3.50 & 3.82 & 6.18 & 4.00 \\
\hline \multirow{2}{*}{ TV Time } & Mean & 6.55 & 7.09 & 7.60 & 4.33 & 4.54 & 6.61 & 7.09 \\
\hline & St. Dev. & 7.12 & 8.69 & 9.15 & 3.41 & 4.62 & 6.28 & 5.49 \\
\hline \multirow{2}{*}{$\begin{array}{l}\text { Time with } \\
\text { Friends }\end{array}$} & Mean & 11.08 & 14.51 & 15.03 & 6.94 & 6.21 & 10.10 & 9.00 \\
\hline & St. Dev. & 11.93 & 14.60 & 15.57 & 6.52 & 4.32 & 9.48 & 8.65 \\
\hline \multirow{2}{*}{$\begin{array}{l}\text { Regular } \\
\text { Breakfast }\end{array}$} & Mean & 5.93 & 5.48 & 5.11 & 6.89 & 7.00 & 5.90 & 6.24 \\
\hline & St. Dev. & 3.30 & 3.56 & 3.63 & 2.33 & 2.16 & 3.28 & 3.33 \\
\hline \multirow{2}{*}{$\begin{array}{l}\text { Relationship } \\
\text { with Parents }\end{array}$} & Mean & 3.42 & 3.38 & 3.31 & 4.08 & 4.15 & 3.10 & 3.14 \\
\hline & St. Dev. & 2.05 & 2.08 & 2.32 & 1.46 & 1.53 & 2.02 & 2.09 \\
\hline \multirow{2}{*}{$\begin{array}{l}\text { Financial Sit } \\
\text { Eval }\end{array}$} & Mean & 2.04 & 2.16 & 1.74 & 2.67 & 2.74 & 1.75 & 1.84 \\
\hline & St. Dev. & 2.47 & 2.54 & 2.68 & 2.08 & 2.08 & 2.49 & 2.38 \\
\hline \multirow{2}{*}{$\begin{array}{l}\text { Health } \\
\text { Physical }\end{array}$} & Mean & 7.84 & 8.23 & 7.97 & 6.97 & 7.23 & 8.07 & 7.88 \\
\hline & St. Dev. & 2.21 & 2.10 & 2.35 & 2.48 & 2.33 & 1.92 & 1.98 \\
\hline \multirow{2}{*}{$\begin{array}{l}\text { Business } \\
\text { Future }\end{array}$} & Mean & 5.55 & 5.69 & 4.78 & 6.56 & 6.87 & 5.37 & 5.13 \\
\hline & St. Dev. & 2.71 & 2.79 & 2.74 & 1.92 & 1.89 & 2.81 & 2.80 \\
\hline \multirow{2}{*}{ Partner } & Mean & 0.51 & 0.38 & 0.55 & 0.79 & 0.82 & 0.34 & 0.46 \\
\hline & St. Dev. & 0.50 & 0.49 & 0.50 & 0.41 & 0.39 & 0.47 & 0.50 \\
\hline \multirow{2}{*}{$\begin{array}{l}\text { Live with } \\
\text { Parents }\end{array}$} & Mean & 0.86 & 0.93 & 0.92 & 0.63 & 0.69 & 0.90 & 0.90 \\
\hline & St. Dev. & 0.35 & 0.25 & 0.27 & 0.48 & 0.46 & 0.30 & 0.30 \\
\hline \multirow{2}{*}{ Age } & Mean & 17.01 & 17.50 & 17.28 & 16.78 & 16.92 & 16.83 & 16.53 \\
\hline & St. Dev. & 1.32 & 1.51 & 1.30 & 0.85 & 0.86 & 1.42 & 1.20 \\
\hline
\end{tabular}

Source: Authors' calculation. 
This would correspond to the fact that in the World Happiness Report 2019 (Helliwell et al., 2019), the average happiness level in the Czech Republic was 6.85 and in Italy 6.22. On the other hand, the Slovenian happiness level in that report was 6.12. This does not support the proposition, because the average reported life satisfaction of Slovenian students in our study is even higher than the Czech average.

We start our analysis by comparing the average values of reported commuting times across genders. To investigate the relationship between commuting time and life satisfaction, we constructed six regression models for each of the six groups presented in Table 2. In each model, the dependent variable is life satisfaction and the independent variables are other factors referred to in Table 1, including commuting time.

Since the dependent variable is measured on a discrete scale from 0 to 10 , it would theoretically be appropriate to apply an ordinal logit model. However, Ferrer-i-Carbonell and Frijters (2004) showed that in such cases with life satisfaction as the dependent variable, when it is theoretically necessary to use probit or logit regression models, an OLS regression method is a sufficient and potentially better alternative. The OLS method is usually preferred because the estimated coefficients are easier to interpret that way. We follow the usual approach in the field of economics of happiness and construct linear OLS regression models in order to find factors related to life satisfaction.

\section{Results and Discussion}

In all the three countries on average, the boys reported a longer commuting time and the boys' standard deviations for commuting time are higher in all the three countries as well. The significance of these differences was confirmed using Levene's test for the equality of variances and the one-tailed Welch's unequal variances t-test. Various explanations for this phenomenon can be formulated: it is possible that boys are willing to sacrifice more of their time to commuting in order to go to a school that better suits their preferences. The second possibility is that girls use a faster means of transport - for example, if cars are faster in the regions of the selected schools, it is possible that girls use cars more often. It could also be the case that boys prolong their commutes for specific reasons (talking to friends, smoking, etc.). Another possibility is that the boys have a different subjective perception of commuting time - that they perceive the same commuting time as being longer. This would be in line with the study of Hanson and Buckworth (2016), who discovered that men have higher time estimations during self-paced running. Schiff and Oldak (1990) gave similar results. However, all of these are only hypotheses and the real cause might not be among them. It is a task for further research to find out whether men tend to report longer commuting times in general and if so, to conduct a more detailed research in order to find out why there is such disparity between genders. 
Table 3: Regression models, dependent variable life satisfaction

\begin{tabular}{|c|c|c|c|c|c|c|c|}
\hline \multirow{2}{*}{ Variable } & & \multicolumn{2}{|c|}{ Czech Republic } & \multicolumn{2}{|c|}{ Italy } & \multicolumn{2}{|c|}{ Slovenia } \\
\hline & & Boys & Girls & Boys & Girls & Boys & Girls \\
\hline \multirow{2}{*}{ Const } & Coeff. & $6.0372^{* * *}$ & $7.7657^{* * *}$ & $8.9930 * * *$ & $6.5745^{* * *}$ & $6.2732^{* * *}$ & $4.7094^{* * *}$ \\
\hline & Std. Error & 0.8608 & 0.8875 & 2.1653 & 2.4989 & 0.8252 & 0.9608 \\
\hline \multirow{2}{*}{$\begin{array}{l}\text { Commuting } \\
\text { Time }\end{array}$} & Coeff. & $-0.0163^{* * *}$ & $-0.0122^{* * *}$ & 0.0004 & 0.0026 & -0.0031 & 0.0013 \\
\hline & Std. Error & 0.0041 & 0.0042 & 0.0063 & 0.0018 & 0.0021 & 0.0085 \\
\hline \multirow{2}{*}{ Population } & Coeff. & $-2.317 e-07$ & $-5.545 e-07$ & $-3.29 e-06$ & $1.63 e-06$ & $-1.28 \mathrm{e}-07$ & $8.46 e-08$ \\
\hline & Std. Error & $2.458 \mathrm{e}-07$ & $3.583 e-07$ & $2.54 \mathrm{e}-06$ & $2.19 \mathrm{e}-06$ & $1.30 \mathrm{e}-06$ & $1.34 \mathrm{e}-06$ \\
\hline \multirow{2}{*}{ Cigarettes } & Coeff. & $-0.0400^{* * *}$ & -0.0086 & -0.0185 & $-0.0604^{* *}$ & $-0.0302^{* *}$ & -0.0094 \\
\hline & Std. Error & 0.0141 & 0.0132 & 0.0213 & 0.0250 & 0.0125 & 0.0142 \\
\hline \multirow{2}{*}{ Allowance } & Coeff. & 0.0020 & 0.0005 & 0.0001 & -0.0013 & 0.0001 & 0.0008 \\
\hline & Std. Error & 0.0013 & 0.0011 & 0.0007 & 0.0009 & 0.0008 & 0.0008 \\
\hline \multirow{2}{*}{ Gifts Spent } & Coeff. & 0.0002 & 0.0001 & $0.0008^{* *}$ & $0.0011^{* * *}$ & -0.0004 & $-0.0001^{* *}$ \\
\hline & Std. Error & 0.0004 & 0.0004 & 0.0004 & 0.0004 & 0.0003 & 0.0001 \\
\hline \multirow{2}{*}{ Sport Time } & Coeff. & -0.0026 & 0.0108 & -0.0377 & 0.0236 & $0.0172 *$ & 0.0149 \\
\hline & Std. Error & 0.0097 & 0.0101 & 0.0320 & 0.0328 & 0.0099 & 0.0161 \\
\hline \multirow{2}{*}{ TV Time } & Coeff. & -0.0028 & $-0.0149 * *$ & -0.0431 & -0.0069 & 0.0142 & 0.0172 \\
\hline & Std. Error & 0.0075 & 0.0064 & 0.0310 & 0.0271 & 0.0098 & 0.0119 \\
\hline \multirow{2}{*}{$\begin{array}{l}\text { Time with } \\
\text { Friends }\end{array}$} & Coeff. & 0.0066 & $0.0081^{* *}$ & -0.0237 & -0.0105 & 0.0052 & $0.0147^{*}$ \\
\hline & Std. Error & 0.0047 & 0.0039 & 0.0174 & 0.0286 & 0.0065 & 0.0075 \\
\hline \multirow{2}{*}{$\begin{array}{l}\text { Regular } \\
\text { Breakfast }\end{array}$} & Coeff. & 0.0223 & 0.0190 & 0.0117 & 0.0568 & $0.0519 * * *$ & $0.0598^{* * *}$ \\
\hline & Std. Error & 0.0184 & 0.0166 & 0.0485 & 0.0583 & 0.0182 & 0.0192 \\
\hline \multirow{2}{*}{$\begin{array}{l}\text { Relationship } \\
\text { with Parents }\end{array}$} & Coeff. & $0.1610^{* * *}$ & $0.2000^{* * *}$ & -0.0831 & 0.0906 & $0.1481^{* * *}$ & $0.1097^{* * *}$ \\
\hline & Std. Error & 0.0332 & 0.0269 & 0.0803 & 0.0865 & 0.0324 & 0.0325 \\
\hline \multirow{2}{*}{$\begin{array}{l}\text { Financial Sit } \\
\text { Eval }\end{array}$} & Coeff. & $0.1128^{* * *}$ & $0.0934^{* * *}$ & 0.0054 & 0.0637 & $0.0889 * * *$ & $0.0559 * *$ \\
\hline & Std. Error & 0.0278 & 0.0235 & 0.0521 & 0.0577 & 0.0255 & 0.0279 \\
\hline \multirow{2}{*}{$\begin{array}{l}\text { Health } \\
\text { Physical }\end{array}$} & Coeff. & $0.1185^{* * *}$ & $0.1342^{* * *}$ & 0.0720 & $-0.1222^{* *}$ & $0.0940^{* * *}$ & $0.1184^{* * *}$ \\
\hline & Std. Error & 0.0316 & 0.0257 & 0.0441 & 0.0519 & 0.0324 & 0.0330 \\
\hline \multirow{2}{*}{$\begin{array}{l}\text { Business } \\
\text { Future }\end{array}$} & Coeff. & -0.0040 & 0.0028 & -0.0852 & 0.0134 & $0.0399^{*}$ & -0.0055 \\
\hline & Std. Error & 0.0230 & 0.0216 & 0.0576 & 0.0691 & 0.0218 & 0.0229 \\
\hline \multirow{2}{*}{ Partner } & Coeff. & $0.3887^{* * *}$ & 0.1577 & $0.5869 * *$ & 0.2617 & $0.2986^{* *}$ & $0.3006^{* *}$ \\
\hline & Std. Error & 0.1341 & 0.1212 & 0.2845 & 0.3381 & 0.1335 & 0.1305 \\
\hline \multirow{2}{*}{$\begin{array}{l}\text { Live with } \\
\text { Parents }\end{array}$} & Coeff. & 0.1680 & $-0.6424^{* * *}$ & -0.1374 & -0.2901 & $-0.550 * * *$ & -0.2957 \\
\hline & Std. Error & 0.2633 & 0.2262 & 0.2273 & 0.2612 & 0.2103 & 0.2288 \\
\hline \multirow{2}{*}{ Age } & Coeff. & -0.0308 & $-0.1105^{* *}$ & -0.1348 & -0.0664 & -0.0046 & 0.0617 \\
\hline & Std. Error & 0.0435 & 0.0462 & 0.1268 & 0.1421 & 0.0441 & 0.0540 \\
\hline R-Squared & & 0.5300 & 0.5700 & 0.5100 & 0.5900 & 0.6400 & 0.6000 \\
\hline
\end{tabular}

Note: T-test significance levels: ${ }^{*}-10 \%$ ( $p$-value lower than 0.1 and higher or equal to 0.05$)$,

** $-5 \%$ ( $p$-value lower than 0.05 and higher or equal to 0.01$),{ }^{* *}-1 \%$ ( $p$-value lower than 0.01$)$.

Source: Authors' calculation. 
Our results indicating that boys have different attitude to or perception of commuting is the main reason why we created separate regression models for boys and girls. The output of the regression analysis is presented in Table 3. The last row of the table shows the R-Squared coefficients for each model.

The commuting time variable is not exogenous. It may be correlated with other unobserved factors. In addition, the causality between independent variables and the dependent variable cannot be determined with certainty. Therefore, we refrain from interpreting the regression results as effects and rather use the term relation. In the case of commuting, it is presumable that the causal effect "commuting to life satisfaction" applies at least to some extent. Therefore, when interpreting the regression results, we consider this possibility and discuss applicative implications.

The main observation that can be drawn from the table is that whereas in the Czech Republic there is a negative relation between commuting time and life satisfaction for both boys and girls, no such relation has been found in Italy and Slovenia. As reported by the Czech schools concerned, the most usual mode of transport of Czech students is by train. On the contrary, the Italian and Slovenian schools reported that their students usually use buses and sometimes a private car. Thus, the fact that the negative relation between commuting and happiness in the Czech Republic does not apply for Italy and Slovenia could be attributed to the means of transport. It seems possible that whereas travelling by Czech trains has a negative effect on life satisfaction, Italians' and Slovenians' happiness is not decreased by commuting because their buses and cars are more convenient. This, however, would be in contradiction with the study of St-Louis et al. (2014) who found that "pedestrians, train commuters and cyclists are significantly more satisfied than drivers, metro and bus users". This possible heterogeneity suggests that different means of transportation might have different effects considering different locations, different quality of transportation vehicles, different quality of traffic organization and possibly different social backgrounds. Therefore, people should not jump to quick conclusions based on the results of a single study. This hypothesis constitutes room for further research.

Another aspect that should be taken into account is that the climate of the Czech Republic is generally colder than the climate of most regions of Italy and Slovenia, including the regions where the investigated schools are situated. Moreover, the questionnaires were distributed in November. It is possible that commuting has a negative effect only if students have to endure cold weather when travelling and changing lines in outdoor stations.

Uchida et al. (2004) showed that predictors of happiness can differ across cultures. Thus, different results between the three countries as far as commuting is concerned could also be attributed to cultural differences and their different perceptions of commuting in general. On the other hand, commuting was not one of the factors investigated in that 
study so its results might not apply to this aspect. Possibly, there can be a psychological aspect that makes commuting less tiresome. For instance, Italians and Slovenians could be more amusable when using public transport, making it a neutral experience.

The regression results further indicate a difference between the relations of commuting and life satisfaction for Czech boys and Czech girls. The commuting coefficient in the boys' regression model is lower (more negative) than in the case of the girls. To determine whether this difference is statistically significant, we conducted an analysis of between-subjects effects. This method is based on the construction of a joint regression model for all Czech students with life satisfaction as the dependent variable and with all the independent variables from the separate models, including commuting time, plus a dummy variable for boys and a variable "commuting time*dummy variable for boys". If the last variable is significant, the test outcome is that the difference between the two groups (here genders) is significant. In our case, this significance is confirmed by the $t$-test and we can thus conclude that the negative relation between commuting time and life satisfaction is stronger for Czech boys than for Czech girls.

Thus, if the "commuting to happiness" causality applies in the case of the Czech students, it can mean that Czech boys are more susceptible to the "damage" caused by commuting than Czech girls. Research conducted among adults points out a different pattern: Lachmann et al. (2017) observed that commuting is a higher psychological burden for women than for men. Roberts et al. (2011) and Munford et al. (2019) made an even stronger claim - their results indicate that commuting lowers the well-being of women but has no influence on the well-being of men at all. Even so, compatibility between our outcomes and these studies can be found in the following: it is possible that young boys perceive commuting as more troublesome than girls do. Later in life, women have more family responsibilities - they usually devote more time to childcare, housework and day-to-day household tasks. In this social model, commuting might be a greater burden for women as was suggested by Roberts et al. (2011). We again accentuate here that this is a hypothesis to be tested.

The commuting time coefficient for Czech boys is 0.0163 and for Czech girls 0.0122 . This means that an increase in commuting time (measured in minutes) by one hour is related with a decrease in life satisfaction by 0.978 for boys and by 0.732 for girls. As mentioned earlier, it is possible that there is an unobserved factor correlated with commuting, which has an influence on life satisfaction. If this was the case, the negative relation between commuting time and happiness could be mediated through the influence of this factor. One aspect that could play this role is the expenditures spent on transportation. It could be the case that the negative effect of commuting on life satisfaction is the result of higher expenditures needed for transportation. In our case, however, this is almost certainly not 
true because the student fares in the Czech Republic are extremely low and paid usually by parents. Still, we cannot rule out the scenario that commuting is connected with other factors. Then, to understand the influence of commuting, it would be necessary to study these factors as well.

As mentioned at the beginning of this chapter, it is presumable that the causality "commuting to life satisfaction" applies at least to some extent. The high OLS coefficients for commuting in the case of the Czech Republic indicate that the measured negative effect of commuting can be very strong. We have already referred to many studies discussing the negative effect of commuting on life satisfaction. Moreover, it can have negative effect on students' academic performance (Tigre et al., 2017). This shows that transportation should be taken into account in policies aiming at promotion of well-being.

We also investigated the emphasis that students put on commuting. To do so, we asked the students "Which of these factors do you think would improve your happiness?" The students were offered various factors of well-being: better health, better relationships with parents, higher income, shorter commuting time, etc. The respondents were allowed mark any number or answer. Out of all the students, only 64 (44 Czechs, 7 Italians and 13 Slovenians) marked "shorter commuting time". In the Czech Republic, a negative relation between commuting time and happiness was found. Only $2.81 \%$ Czechs see shorter commuting as a potential source of increasing their happiness despite the fact that $62 \%$ of them (of all Czech students) commute more than 40 minutes every day. If the "commuting to happiness" causality applies here (negative effect of commuting), then this shows that commuting is an underestimated factor among the Czechs in our sample. This would support the claim of Lorenz (2018), as well as Stutzer and Frey (2004), who presented commuting as one of the most underestimated factors altogether. This highlights the importance of happiness research: people who receive this information about commuting can restructure their life priorities and thus improve their quality of life while keeping their resources used constant. An economist would rejoice at the fact that utility was increased with zero additional cost.

\section{Conclusion}

Our analysis of the relation between high school students' commuting time and life satisfaction suggests differences between genders and between investigated countries. Firstly, boys reported significantly higher values of commuting time. This probably points either to different commuting behaviour of boys or to a different perception of commuting time between genders.

Secondly, while the relation between commuting time and life satisfaction in the Czech Republic is negative, there is no relation between the aforementioned factors in Italy and 
in Slovenia. Considering the "commuting to life satisfaction" causality, there are three quite relevant possible explanations: the main means of transportation of Czech students is the train, whereas most students in Italy and Slovenia commute by bus or by private car. Therefore, the mode of transportation may affect the commuting experience. Here, buses and cars seem to be a more convenient way to spend one's early morning hours. Another important aspect is climate: commuting might be more burdensome for Czech students because of the relatively colder weather - freezing on a train platform is probably more painful than sitting on an Italian bus. A third possible reason for differences between the countries might be the diversity in mentalities: Czechs might be more susceptible to suffer from commuting because of their psychological setting. All these hypotheses create space for further research.

Further, our analysis indicates a more negative effect of commuting on boys. Many studies show that commuting affects adult women more negatively than men. Thus, it is possible that the more negative effect of commuting on women comes with adulthood and the many responsibilities adult women usually take on.

The high regression coefficients in absolute value for the Czech students indicate (yet do not confirm with certainty) a possibility of a strong influence of commuting on life satisfaction. Therefore, this aspect should not be neglected in future research. The vast majority of the students do not believe that shorter commuting could make them happier. Along with the possibility of strong influence of commuting on life satisfaction, this shows that commuting is most likely a much underestimated factor. This implies that a person looking for a higher level of life satisfaction might want to take commuting into account more seriously.

Our results show that there are potentially many differences in the way commuting affects people's well-being depending on the region, cultural background, mode of transportation, quality of transportation vehicles, personality traits, etc. Thus, the varied results of the studies mentioned in the introductory part of this paper might not be contradictory after all. Yet, it is likely that the effect of non-active commuting is usually negative.

Our analysis indicates (yet does not confirm with certainty) that in the Czech Republic, commuting has a negative effect on students' well-being and is underrated. If the effect of commuting is underestimated throughout society, it is possible that the current transportation infrastructure is undersized. In such a case, improvements in the transportation network with benefits higher than costs could be implemented. Commuting times could be reduced in order to increase people's well-being while keeping the costs on an acceptable level. This may serve as a guide for further political consideration and public policy. 


\section{References}

Astin, A. W. (1984). Student Involvement: A Developmental Theory for Higher Education. Journal of College Student Personnel, 25(4), 297-308.

Biddix, P. (2015). Strategies for Assessing Commuter Students, in Biddix, P., ed., Understanding and Addressing Commuter Student Needs: New Directions for Students Service. San Francisco, CA: Jossey Bass, pp. 97-107, https://doi.org/10.1002/ss.20131

Diener, E., Lucas, R., Schimmack, U. et al. (2009). Well-being for Public Policy. Oxford University Press. ISBN 9780195334074.

Ferrer-i-Carbonell, A., Frijters, P. (2004). How Important is Methodology for the Estimates of the Determinants of Happiness? Economic Journal, 114(497), 641-659, https://doi.org/10.1111/j.1468-0297.2004.00235.x

Fordham, L., van Lierop, D., El-Geneidy, A. (2017). Can't get no Satisfaction: Examining the Influence of Commuting on Overall Life Satisfaction. Paper presented at 96thTransportation Research Board Annual Meeting, Washington D.C., USA.

Fordyce, M. W. (1988). A Review of Research on the Happiness Measures: A Sixty-second Index of Happiness and Mental Health. Social Indicators Research, 20(4), 355-381, http://doi.org/10.1007/BF00302333

Frey, B. S., Stutzer, A. (2004). Stress That Doesn't Pay: The Commuting Paradox. Institute for Empirical Research in Economics, University of Zurich. Working Paper No. 151.

Frey, B. S. (2008). Happiness: a Revolution in Economics. Cambridge: MIT Press. ISBN 978-0-262-06277-0.

Frey, B. S., Stutzer, A. (2010). Happiness and Public Choice. Public Choice, 144(3-4), 557-573, http://doi.org/10.1007/s11127-010-9681-y

Hanson, N. J., Buckworth, J. (2016). Sex Differences in Time Perception during Self-paced Running. International Journal of Exercise Science, 9(3), 514-523, http://doi.org/10.1249/01.mss.0000495273.21843.8f

Helliwell, J. (2006). Well-Being, Social Capital and Public Policy: What's New? The Economic Journal, 116(510), C34-C45, http://doi.org/10.1111/j.1468-0297.2006.01074.x

Helliwell, J., Layard, R., Sachs, J. (2018). World Happiness Report 2018. New York: Sustainable Development Solutions Network. ISBN 978-0-9968513-6-7.

Helliwell, J., Layard, R., Sachs, J. (2019). World Happiness Report 2019. New York: Sustainable Development Solutions Network. ISBN 978-0-9968513-9-8.

Chatterjee, K., Clark, B., Martin, A. et al. (2017). The Commuting and Wellbeing Study: Understanding the Impact of Commuting on People's Lives. University of the West of England.

Chickering, A. (1974). Commuting versus Resident Students: Overcoming the Educational Inequities of Living Off Campus. San Francisco: Jossey-Bass. ISBN 978-0875892313. 
Kahneman, D., Riis, H. (2005). Living and Thinking about It: Two Perspectives on Life, in Huppert, F., Baylis, N., Keverne, B., ed., The Science of Well-Being. Oxford: Oxford University Press, pp. 285-304, https://doi.org/10.1093/acprof: oso/9780198567523.003.0011

Lachmann, B., Sariyska, R., Kannen, Ch. et al. (2017). Commuting, Life-Satisfaction and Internet Addiction. International Journal of Environmental Research and Public Health, 14(10), http://doi.org/10.3390/ijerph14101176

Legrain, A., Eluru, N., El-Geneidy, A. (2015). Am Stressed, Must Travel: The Relationship between Mode Choice and Commuting Stress. Transportation Research Part F: Traffic Psychology and Behaviour, 34, 141-151, https://doi.org/10.1016/j.trf.2015.08.001

Lorenz, O. (2018). Does Commuting Matter to Subjective Well-being? Journal of Transport Geography, 66, 180-199, http://doi.org/10.1016/j.jtrangeo.2017.11.019

Munford, L., Rice, N., Roberts, J. et al. (2019). The Disutility of Commuting? The Effect of Gender and Local Labour Markets. Regional Science and Urban Economics, 77, 264-275, https://doi.org/10.1016/j.regsciurbeco.2019.06.001

Roberts, J., Hodgson, R., Dolan, P. (2011). “It's Driving her Mad": Gender Differences in the Effects of Commuting on Psychological Health. Journal of Health Economics, 30(5), 1064-1076, https://doi.org/10.1016/j.jhealeco.2011.07.006

Rode, J., Arthaud-Day, M., Mooney, Ch. et al. (2005). Life Satisfaction and Student Performance. Academy of Management Learning and Education, 4(4), 421-433, https://doi.org/10.5465/amle.2005.19086784

Schiff, W., Oldak, R. (1990). Accuracy of Judging Time to Arrival: Effects of Modality, Trajectory, and Gender. Journal of Experimental Psychology: Human Perception and Performance, 16(2), 303-316, http://doi.org/10.1037/0096-1523.16.2.303

St-Louis, E., Manaugh, K., van Lierop, D. et al. (2014). The Happy Commuter: A Comparison of Commuter Satisfaction across Modes. Transportation Research Part F: Traffic Psychology and Behaviour, 26, 160-170, https://doi.org/10.1016/j.trf.2014.07.004

Tigre, R., Sampaio, B., Menezes, T. (2017). The Impact of Commuting Time on Youth's School Performance. Journal of Regional Science, 57(1), 28-47, http://doi.org/10.1111/jors.12289

Uchida, Y., Norasakkunkit, V., Kitayama, S. (2004). Cultural Constructions of Happiness: Theory and Empirical Evidence. Journal of Happiness Studies, 5(3), 223-229, https://doi.org/10.1007/s10902-004-8785-9

Whalen, K., Paéz, A., Carrasco, J. (2013). Mode Choice of University Students Commuting to School and the Role of Active Travel. Journal of Transport Geography, 31, 132-142, https://doi.org/10.1016/j.jtrangeo.2013.06.008

Ying, S., Yang, L., Fang-Biao, T. (2015). Associations between Active Commuting to School, Body Fat, and Mental Well-being: Population-Based, Cross-Sectional Study in China. Journal of Adolescent Health, 57(6), 679-685, https://doi.org/10.1016/j. jadohealth.2015.09.002 